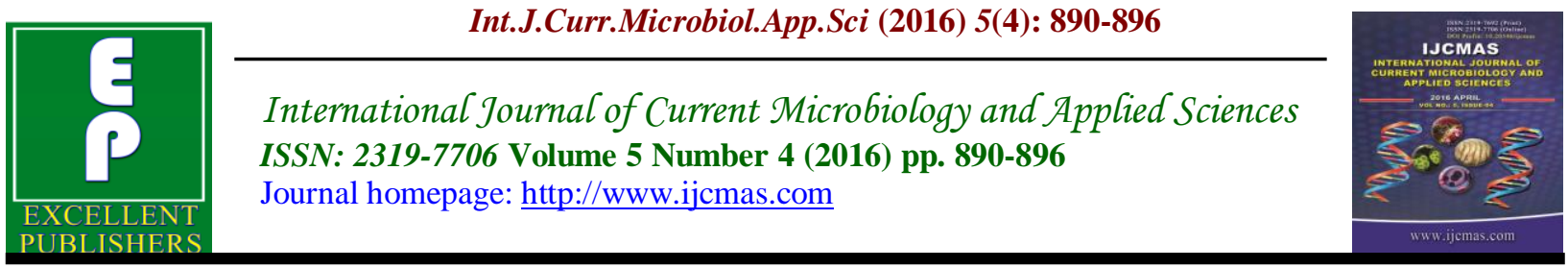

Original Research Article

http://dx.doi.org/10.20546/ijcmas.2016.504.100

\title{
Effect of container size on the growth and development of tomato seedlings
}

\author{
Otsoseng Oagile ${ }^{1 *}$, Pitso Gabolemogwe ${ }^{1}$, Christinah Matsuane ${ }^{1}$ \\ and Thembinkosi Mathowa ${ }^{1}$
}

\author{
Botswana University of Agriculture and Natural Resources, Private Bag 0027 \\ Gaborone, Botswana \\ *Corresponding author
}

Keywords

Tomato seedlings, growth and development, container and cell size

\section{Article Info}

Accepted:

25 March 2016

Available Online:

10 April 2016
A B S T R A C T

Seedlings growth and development of tomato (Lycopersicon esculentum L.) as influenced by various container size was evaluated at Botswana University of Agriculture and Natural Resources (formerly Botswana College of Agriculture) from March-April 2015. Propagation containers with different cell sizes (volumes of $18.5 \mathrm{~cm}^{3}, 65 \mathrm{~cm}^{3}$ and $170 \mathrm{~cm}^{3}$ being treatments) were used. The experiment was laid as a completely randomized design (CRD) with four repetitions. Tomato seedlings were grown in a net shade house of $80 \%$. The following growth and development parameters were recorded; plant height, leaf number and area, and shoot fresh and dry weights. Data was subjected to analysis of variance (ANOVA). Plant height showed a non-significant $(\mathrm{p}>0.05)$ difference in response to treatments in the first three weeks followed by a highly significant $(\mathrm{p}<0.01)$ response in the fourth week. The latter response was revealed for leaf number and area, and shoot fresh and dry weights except for a significant $(\mathrm{p}<0.05)$ response in week two for leaf number. Generally bigger $\left(170 \mathrm{~cm}^{3}\right)$ cells significantly enhanced the performance of the seedlings as compared to smaller $\left(18.5 \mathrm{~cm}^{3}\right)$ cells. As a result the bigger cells are recommended as the most desirable containers for quality seedlings.

\section{Introduction}

Tomato (Lycopersicon esculentum L.) is one of the most cultivated vegetable food crop in most regions of the world, ranking second in importance to potatoes (Solanum tuberosum L.) (Anastacia et al., 2011; FAO, 2015). It is a member of the Solanaceae family, which includes chilli peppers, bell peppers, eggplant, Irish potato and tobacco (Heuvelink, 2005). Tomato seedlings are usually grown in controlled environments structures such as greenhouses and growth chambers using containers of different cell sizes. The containers are required to hold the growing medium (Ray and Sinclair, 1998) and container sizes are key components for the growth and survival of seedlings. Container size has a huge effect on plant growth and it may affect root and shoot growth, biomass accumulation and partitioning, photosynthesis, leafchlorophyll content, plant water relations, nutrient uptake, respiration and flowering (Al-Menaie et al., 2012). Physiological 
experiments are sometimes conducted in controlled environments where plants are grown in containers with limited soil volume. A well-recognized problem with growing plants under these conditions is the possibility that the plants may become root bound. Numerous studies have shown a general reduction in growth associated with small container sizes (Kratky et al., 1982; Peterson et al., 1984; Robbins and Pharr, 1988; Cantliffe, 1993; Townend and Dickinson, 1995; Whitfield et al., 1996; NeSmith and Duval, 1998; Schrader, 2000; Al-Menaie et al., 2012). These reductions in growth have been shown to occur in both solid media as well as in hydroponic nutrient solution. On a positive note, according to Schrader (2000), smaller containers or cells reduce production costs.

The effect of container size and root restriction on leaf growth has been documented for several crops; soybean (Krizek et al., 1985), tomato (Weston and Zandstra, 1986), bell pepper (Weston, 1988), marigold (Latimer, 1991), euonymus (Dubik et al., 1992), squash (NeSmith, 1993), cabbage (Csizinszky and Schuster, 1993), watermelon (Liu and Latimer, 1995) and salvia (Van Iersel, 1997). In all cases, as rooting volume decreased, leaf area also decreased. Shoot growth is greatly impacted by varying container size and root restriction. Reduction in shoot growth and biomass as a result of small containers has been reported for tomato (Peterson et al., 1991), marigold (Latimer, 1991), watermelon (Hall, 1989; Liu and Latimer, 1995) and muskmelon (Maynard et al., 1996). Hall (1989) also noted that the rate of vine growth was greater in plants grown in larger cells than in smaller ones once transplanted to the field.

Transplants for both vegetable and floral crops are produced in a number of various sized containers or cells. Varying container size alters the rooting volume of the plants, which can greatly affect plant growth. The issue of container size is extremely important for transplant producers as they seek to optimize production space with smaller sized containers whereas consumers are interested in larger sized containers as it relates to optimum post-transplant performance. A trend among many commercial transplant producers is towards more cells per tray (smaller containers) which increases number of plants produced and reduce production costs (Schrader, 2000) while reducing the need to develop more transplant production space (NeSmith and Duval, 1998). Moreover, the plant's adaptation to transplanting and its ability to reestablish normal growths quickly in the field are important considerations when determining the most desirable cell size.

Other than varying sizes of containers or cells tomato productivity is also influenced by transplants management. Vavrina and Orzolek (1993) in a review of tomato transplant age noted that transplants quality is affected by numerous factors such as water supply, fertilization and substrate used. Therefore if no limitations are imposed on seedling management container size remain an important factor for consideration. Seedling trays are available locally with varying cell size and/or volume; therefore it is up to the grower to choose the best container to produce strong and vigorous transplants. If it calls for few cells per container (large containers) then more than one container could be used to produce more seedlings and vice versa. Despite the wide uses of containerized tomato seedlings and the need for more cells per container, information on how container size affect transplant growth and development of tomato seedlings is still considerably limited hence the need for the study reported in this paper. 


\section{Materials and methods}

\section{Experimental site}

The study was conducted in a $80 \%$ net shade house at the Botswana University of Agriculture and Natural Resources (BUAN) formerly Botswana College of Agriculture, Sebele campus. Sebele is located between latitude $24^{\circ} 33^{\prime} \mathrm{S}$ and longitude $25^{\circ} 54^{\prime} \mathrm{E}$ at an elevation of $994 \mathrm{~m}$ above sea level.

\section{Experimental design and planting}

A completely randomized design (CRD) with three treatments repeated four times was used. The three treatments were plastic seedling containers [WEBCO (Pty) Ltd., Gauteng, South Africa; www.webcotools.co.za] of varying cell sizes or volumes of $18.5,65$ and $170 \mathrm{~cm}^{3}$. Tomato seeds (rodade variety) were sown in seedlings containers filled with hygromix [Hygrotech (Pty) Ltd., Pretoria North, South Africa; www.hygrotech.co.za].

\section{Cultural practices}

Seedlings were watered in the morning and afternoon throughout the duration of the study. Water soluble multifeed $P$ ( $5: 2: 4$ (43) (Plaaskem (Pty) Ltd., Witfield, South Africa) fertilizer was applied once weekly after development of true leaves to boost the seedlings. Seedlings were also scouted daily for incidences of pests and diseases.

\section{Measured parameters}

Measurements of leaf number and plant height were collected weekly after development of true leaves on eight predetermined and tagged seedlings in the middle of the seedling tray from each repetition until termination of experiment. Plant height was measured using a $30 \mathrm{~cm}$ ruler from the base to the terminal leaf. At termination of experiment, 10 plants were randomly sampled and their leaf area was measured using leaf area meter- A3 lightbox (Delta-T Devices Ltd, Cambridge, England). All tagged seedlings were harvested and placed into weighing brown paper bag for determination of fresh and dry weights using an electronic balance- PGW 4502e (Adam®, Smith-Hamiltom, Inc., Miami Florida, US; www.adamequipment.com). The samples were oven dried to constant weight at $80^{\circ} \mathrm{C}$ using a hot air oven- Scientific Series 2000[Laval Lab, Inc., Laval (Quebec), Canada; http://lavallab.com].

\section{Data analysis}

Data was subjected to analysis of variance (ANOVA) using Analytical Software (2003). Where a significant F-test was used and means comparison tests carried out using Least Significant Difference (LSD) at $\mathrm{p} \leq 0.05$.

\section{Results and Discussion}

\section{Plant height}

A non-significant $(\mathrm{p}>0.05)$ treatment effect was revealed in weeks 1 to 3 whereas a highly significant $(\mathrm{p}<0.01)$ treatment effect was revealed in week 4. Bigger cells (170 $\mathrm{cm}^{3}$ ) followed by $65 \mathrm{~cm}^{3}$ significantly increased the plant height as compared to the smaller cells $\left(18.5 \mathrm{~cm}^{3}\right)$ (Table 1$)$.The significant difference in plant height across the treatments is attributed to the varying container or cell sizes. This in line with the previous findings (Kratky et al., 1982; Peterson et al., 1984; Robbins and Pharr, 1988; Cantliffe, 1993; Townend and Dickinson, 1995; Whitfield et al., 1996; NeSmith and Duval, 1998; Schrader, 2000; Al-Menaie et al., 2012) who concluded that a reduction in container cell size increased the potential of root restriction and reduction 
in plant growth is associated with small container size. According to Robbins and Pharr (1988) container size has been shown to affect a number of physiological processes including nutrient efficiency and photosynthesis rates although the relationship between photosynthesis rate and container size has not been consistent. Reduction in container cell size limits resources such as nutrients, available growth medium and space for roots to spread and as such root restriction will result in reduced plant growth.

\section{Leaf number}

There were significant $(\mathrm{p}<0.05)$ treatment differences revealed from weeks 2 to 4 in both leaf number and area. Containers with bigger $\left(170 \mathrm{~cm}^{3}\right)$ cells significantly increased the leaf number and area as compared to the ones with smaller (18.5 $\mathrm{cm}^{3}$ ) cells (Table 2). These significant differences are attributed to varying container cell sizes. Elsewhere, studies revealed positive and negative results for different crops with increase in rooting volume and vice versa respectively (Krizek et al., 1985; Weston and Zandstra, 1986;
Weston, 1988; Latimer, 1991; Dubik et al., 1992; Csizinszky and Schuster, 1993; NeSmith, 1993; Liu and Latimer, 1995; Van Iersel, 1997). It is evident that reduction in container cell size led to reduced space for roots to spread which affect the uptake of available minerals from the growth medium and indirectly affecting other physiological processes such as photosynthesis and respiration (Robbins and Pharr, 1988). Leaves present the plant assimilation system necessary for photosynthesis upon which a plant can develop its vegetative mass.

\section{Shoot (fresh and dry) weights}

Shoot (fresh and dry) weights were significantly $(\mathrm{p}<0.01)$ affected by varying container sizes with the highest fresh and dry weights recorded for transplants grown in $170 \mathrm{~cm}^{3}$ cells followed by $65 \mathrm{~cm}^{3}$ and $18.5 \mathrm{~cm}^{3}$ cells respectively (Table 3 ). These significant differences are attributed to varying container sizes and the consequences of the previous parameters (plant height, leaf number and area) which were significant throughout the study. Shoot growth is greatly impacted by varying container size and root restriction.

Table.1 Effect of container size on tomato plant height $(\mathrm{cm})$

\begin{tabular}{lcccc}
\hline Container size & \multicolumn{4}{c}{ Plant height (weeks after development of true leaves) } \\
\cline { 2 - 5 } & Week 1 & Week 2 & Week 3 & Week 4 \\
\hline Cell size-18.5 cm & 4.53 & 11.34 & 22.84 & $23.67^{\mathrm{c}}$ \\
Cell size-65 cm & 4.20 & 10.63 & 26.22 & $28.87^{\mathrm{b}}$ \\
Cell size-170 cm & 4.37 & 9.95 & 24.82 & $33.56^{\mathrm{a}}$ \\
\hline Significance & $\mathrm{ns}$ & $\mathrm{ns}$ & $\mathrm{ns}$ & $* *$ \\
LSD (0.05) & $\mathrm{ns}$ & $\mathrm{ns}$ & $\mathrm{ns}$ & 4.46 \\
CV $(\%)$ & 7.11 & 6.03 & 11.26 & 7.78 \\
\hline
\end{tabular}

** Highly significant at $\mathrm{p}<0.01,{ }^{\mathrm{ns}}$ non-significant at $\mathrm{p}>0.05$. Means separated by Least Significant Difference (LSD) Test at $p \leq 0.05$, means within columns followed by the same letters are not significantly different. 
Table.2 Effect of container size on tomato leaf number and leaf area $\left(\mathrm{cm}^{2}\right)$

\begin{tabular}{|c|c|c|c|c|c|}
\hline \multirow[t]{3}{*}{ Container size } & \multicolumn{5}{|c|}{ Weeks after development of true leaves } \\
\hline & \multicolumn{4}{|c|}{ Leaf number } & Leaf area \\
\hline & Week 1 & Week 2 & Week 3 & Week 4 & Week 4 \\
\hline Cell size- $18.5 \mathrm{~cm}^{3}$ & 2 & $2.71^{b}$ & $3.21^{\mathrm{b}}$ & $4.73^{b}$ & $34.96^{\mathrm{c}}$ \\
\hline Cell size $-65 \mathrm{~cm}^{3}$ & 2 & $3.25^{\mathrm{ab}}$ & $4.96^{\mathrm{a}}$ & $5.21^{\mathrm{b}}$ & $75.48^{\mathrm{b}}$ \\
\hline Cell size- $170 \mathrm{~cm}^{3}$ & 2 & $3.58^{\mathrm{a}}$ & $5.21^{\mathrm{a}}$ & $6.88^{\mathrm{a}}$ & $196.26^{\mathrm{a}}$ \\
\hline Significance & - & $*$ & $* *$ & $* *$ & $* *$ \\
\hline LSD $(0.05)$ & - & 0.59 & 0.92 & 1.02 & 3.58 \\
\hline $\mathrm{CV}(\%)$ & - & 9.26 & 10.36 & 9.07 & 1.75 \\
\hline
\end{tabular}

Table.3 Effect of container size on tomato shoot (fresh and dry) weights

\begin{tabular}{lcc}
\hline Container size & \multicolumn{2}{c}{ Shoot weight } \\
\cline { 2 - 3 } & Fresh weight $(\mathrm{g})$ & Dry weight $(\mathrm{g})$ \\
\hline Cell size-18.5 cm & $5.13^{\mathrm{c}}$ & $0.25^{\mathrm{c}}$ \\
Cell size-65 cm & $11.96^{\mathrm{b}}$ & $1.00^{\mathrm{b}}$ \\
Cell size-170 cm & $19.63^{\mathrm{a}}$ & $1.33^{\mathrm{a}}$ \\
\hline Significance & $* *$ & $* *$ \\
LSD $(0.05)$ & 0.71 & 0.17 \\
CV $(\%)$ & 2.19 & 9.68 \\
\hline
\end{tabular}

** Highly significant at $\mathrm{p}<0.01$. Means separated by Least Significant Difference (LSD) Test at $\mathrm{p} \leq 0.05$, means within columns followed by the same letters are not significantly different.

Shoot height and fresh weights reduction in small containers has been reported for tomato (Peterson et al., 1991) and other crops elsewhere (Hall, 1989; Latimer, 1991; Liu and Latimer, 1995; Maynard et al., 1996). Moreover, consistent reports elsewhere concluded that large differences existed in shoot dry weights for varying container sizes (Peterson et al., 1984; Robbins and Pharr, 1988; Townend and Dickinson, 1995; Whitfield et al., 1996). According to NeSmith et al., (1992), reduced plant weights under root restricting conditions could possibly be due to a lower photosynthetic rate; although, few container size or root restriction studies have measured photosynthetic rate.

In conclusion, Bigger $\left(170 \mathrm{~cm}^{3}\right)$ cells enhanced tomato seedlings growth and development with respect to plant height, leaf number and area, and shoot fresh and dry weights. This signifies that for quality seedlings, bigger containers are the most desirable.

\section{Acknowledgement}

We owe our gratitude to Botswana University of Agriculture and Natural Resources for providing the required facilities.

\section{References}

Al-Menaie, H. S., Al-Ragam, O., Al-Dosery, N., Zalzaleh, M., Mathew, M. and Suresh, N. 2012. Effect of pot size on plant growth and multiplication of water lilies (Nymphaea spp). 
American-Eurasian Journal of Agriculture \& Environmental Science. 12, 148-153.

Analytical Software. 2003. STATISTIX 8 for Windows. Tallahassee, Florida, US.

Anastacia, M. A. O., Thomas, K. K. and Hilda, W. N. 2011. Evaluation of tomato (Lycopersicon esculentum L.) variety tolerance to foliar diseases at Kenya Agricultural Research Institute Centre-Kitale in Northwest Kenya. African Journal of Plant Science. 5(11), 676-681.

Cantliffe, D. J. 1993. Pre and postharvest practices for improved vegetable transplant quality. Horticultural Technology. 3, 415-417.

Csizinszky, A. A. and Schuster, D. J. 1993. Impact of insecticide schedule, $\mathrm{N}$ and $\mathrm{K}$ rates and transplant container size on cabbage yield. Horticultural Science. 28, 299-301.

Dubik, S. P., Krizek D. T., Stimart, D. P. and McIntosh, M. S. 1992. Growth analysis of spreading euonymus subjected to root restriction. Journal Plant Nutrition. 15, 469-486.

FAO. 2015.2 FAOSTAT3. http://faostat3.fao.org. Available online, retrieved 09-03-2016.

Hall, M. R. 1989. Cell size of seedling containers influences early vine growth and yield of transplanted watermelon. Horticultural Science. 24, 771-773.

Heuvelink, E. (ed).2005. Tomatoes. CABI Publishing, USA.

Kratky, B. A., Wang, J. K. and Kubojiri, K. 1982. Effect of container size, transplant age, and plant spacing on Chinese cabbage. Journal of the American Society for Horticultural Science. 107, 345-347.

Krizek, D. T., Carmi, A., Mirecki, R. M., Snyder, F. W. and Bruce, J. A. 1985.
Comparative effects of soil moisture stress and restricted root zone volume on morphogenetic and physiological responses of soybean (Glycine max L. Merr.). Journal of Experimental Botany. 36, 25-38.

Latimer, J. G. 1991. Container size and shape influence growth and landscape performance of marigold seedlings. Horticultural Science. 26, 124-126.

Liu, A. and Latimer, J. G. 1995. Root cell volume in the planter flat affects watermelon seedling development and fruit yield. Horticultural Science. 30, 242-246.

Maynard, E. T., Vavrina, C. S. and Scott, W. D. 1996. Containerized muskmelon transplants: Cell volume effects on pre-transplant development and subsequent yield. Horticultural Science. 31, 58-61.

NeSmith, D. S. 1993. Influence of root restriction on two cultivars of summer squash (Cucurbita pepo L.). Journal of Plant Nutrition. 16, 421-431.

NeSmith, D. S., and Duval, J. R. 1998. The effect of container size. Horticultural Technology. 8, 495-498.

NeSmith, D. S., Bridges, D. C., and Barbour, J. C. 1992. Bell pepper responses to root restriction. Journal of Plant Nutrition. 15, 2763- 2776.

Peterson, C. M., Klepper, B., Pumphrey, F. V. and Rickman, R. W. 1984. Restricted rooting decrease tillering and growth of winter wheat. Agronomy Journal. 76, 861-863.

Peterson, T. A., Reinsel, M. D. and Krizek, D. T. 1991. Tomato (Lycopersicon esculentum Mill. cv 'Better Bush) plant response to root restriction. Alteration of plant morphology. Journal of Experimental Botany. 42, 1233-1240.

Ray, J. D. and Sinclair, T. R. 1998. The effect of pot size on growth and 
transpiration of maize and soybean during deficit stress. Journal of Experimental Botany. 49,1381-1386.

Robbins, N. S. and Pharr, D. M. 1988. Effect of restricted root growth on carbohydrate metabolism and whole plant growth of Cucumis sativus L. Plant Physiology. 87, 409-413.

Schrader, W. L. 2000. Using transplants in vegetable production. Publication 8013 by Division of Agriculture and Natural Resource, University of California.

http://anrcatalog.ucdavis.edu/pdf/8013 .pdf. Available online, retrieved 1010-2014.

Townend, J. and Dicknson, A. L. 1995. A comparison of rooting environments in containers of different sizes. Plant and Soil. 175, 139-146.

Van Iersel, M. 1997. Root restriction effects on growth and development of salvia
(Salvia splendens). Horticultural Science. 32, 1186-1190.

Vavrina, C.S. and Orzolek, M. 1993. Tomato transplants age: A review. Horticultural Technology. 3, 313-316.

Weston, L. A. 1988. Effect of flat cell size, transplant age, and production site on growth and yield of pepper transplants. Horticultural Science. 23, 709-711.

Weston, L.A. and Zandstra, B. H. 1986. Effect of root container size and location of production on growth and yield of tomato transplants. Journal of American Society Horticultural Science. 111, 498-501.

Whitfield, C. P., Davison, A. W. and Ashenden, T. W. 1996. Interactive effects of ozone and soil volume on Plantago major.The New Phytologist. 134(2), 287-294.

\section{How to cite this article:}

Otsoseng Oagile, Pitso Gabolemogwe, Christinah Matsuane and Thembinkosi Mathowa. 2016. Effect of container size on the growth and development of tomato seedlings. Int.J.Curr.Microbiol.App.Sci.5(4): 890-896. doi: http://dx.doi.org/10.20546/ijcmas.2016.504.100 